TOPIC III.B

PAMELA SAMUELSON

\title{
The Originality Standard for Literary Works Under U.S. Copyright Law
}

In common parlance the term "literary work" means works of literature. If this was all it meant in U.S. copyright law, a report on the originality standard for literary works would be very short indeed. ${ }^{1}$ However, the U.S. copyright statute defines "literary works" far more broadly than this as "works, other than audiovisual works, expressed in words, numbers, or other verbal or numerical symbols or indicia, regardless of the nature of the material objects, such as books, periodicals, manuscripts, phonorecords, film, tapes, disks, or cards, in which they are embodied." 2 This definition encompasses compilations of facts, a broad range of other kinds of factual works (such as histories and scientific reports), business forms, charts, and computer software. Because some of these works, or certain aspects of them, are often at the borderline of the copyright realm, a report on the originality standard for statutory literary works must, of necessity, be more extensive. Not only have there been a large number of cases on which to report, but a surprisingly wide range of originality issues have been raised in them as well.

Pamela Samuelson is Professor of Law, University of Pittsburgh School of Law.

This paper has been prepared for delivery at the 1994 World Congress of Comparative Law that will be held in Athens, Greece, July 31-August 6, 1994. The author wishes to thank Jim Weinberg for his considerable research assistance with this project and to express appreciation to Professors Ralph Brown, Jessica Litman and Ray Patterson for their helpful comments on an earlier draft of this paper.

1. Works of literature easily pass U.S. copyright's originality test. Disputes about originality in work of literature cases tend to arise only when the chief defense is that what was taken from the plaintiff's work pertained to standard plot elements, see, e.g., Denker v. Uhry, 820 F. Supp. 722, 731-34 (S.D.N.Y. 1992) ("Driving Miss Daisy" did not infringe copyright in "Horowitz and Mrs. Washington" in part because similarities pertained to standard plot elements not original to plaintiff) or that the copied element had been taken from a work other than that in which the plaintiff held a valid copyright, see, e.g., Shaw v. Lindheim, 809 F. Supp. 1393 (C.D. Cal. 1992) (no infringement of copyright in a derivative work because the principal similarities between the works were as to elements of an underlying work in the public domain that had been incorporated into the plantiff's derivative script).

2. 17 U.S.C. $\$ 101$ (definition of "literary work")(1988). Notice that the definition is so broad that without the explicit exclusion, audiovisual works would be included. Some implications of this broad definition are explored infra nn. 139-44 and accompanying text. 
The most significant development in the US copyright caselaw concerning the originality standard is unquestionably the U.S. Supreme Court decision, Feist Publications, Inc. v. Rural Telephone Service Co., ${ }^{3}$ in which the Court ruled that the white pages listings of a telephone directory did not exhibit sufficient creativity in selection, coordination, or arrangement of data to satisfy the originality standard of U.S. copyright law.

Although the Feist decision has been hailed abroad as an important advance destined to bring U.S. law more in harmony with Continental European and Japanese authors' rights systems, ${ }^{4}$ it has met with a distinctly mixed reaction in the United States. ${ }^{5}$ Some have applauded it as a long overdue rejection of the "sweat of the brow" (or industrious collection) theory of originality ${ }^{6}$ which, as Professor Ginsburg has shown, has had a rather considerable history in U.S. copyright law. ${ }^{7}$ Much of the criticism of Feist by U.S. commentators has

3. 111 S.Ct. 1282 (1991).

4. See, e.g., Remarks of Jean F. Verstrynge, Proceedings Of SOFTIC's Third International Symposium On Legal Protection Of Computer Programs 190 (1991) (remarking that the Feist opinion was so consistent with the Continental European position that it could have been written by a French or German judge) (cited hereinafter as "SOFTIC Proceedings") and Pattison, "The European Commission's Proposal on the Protection of Computer Databases," 1992 Eur. Intell. Prop. Rev. 113, 113-14 (April 1992) (reporting that the United Kingdom is now alone in protecting "sweat of the brow" compilations).

5. See, e.g., articles in symposium issues on Feist published in $17 \mathrm{U}$. Dayton $L$. $R e v$., issues 2 and 3 (1992) (expressing a range of views on Feist and its implications). Among the many other scholarly commentaries on Feist are: Abrams, "Originality and Creativity in Copyright Law," 55 Law \& Contemp. Prob. 3 (1992); Dreyfuss, "A Wiseguy's Approach to Information Products: Muscling Copyright and Patent Into a Unitary Theory of Intellectual Property," 1992 Sup. Ct. Rev. 195 (1992); Ginsburg, "No 'Sweat'? Copyright and Other Protection of Works of Information After Feist $v$. Rural Telephone," 92 Colum. L. Rev. 338 (1992); Gordon, "Reality As Artifact: From Feist to Fair Use," 55 Law \& Contemp. Prob. 93 (1992); Gorman, "The Feist Case: Reflections on a Pathbreaking Copyright Decision," 18 Rutg. Comp. \& Techn. L.J. 731 (1992); Heald, "The Vices of Originality," 1991 Sup. Ct. Rev. 143 (1992), Samuelson, "Copyright Law and Electronic Compilations of Data," 35 Comm. ACM 27 (Feb. 1992); Yen, "The Legacy of Feist: Consequences of the Weak Connection Between Copyright and the Economics of Public Goods," 52 Ohio St. L. J. 1343 (1991) and sources cited infra $\mathrm{nn} .6,9$, and 12 .

6. Among those most enthusiastic about Feist's rejection of the sweat of the brow theory are Patterson, "Copyright Overextended: A Preliminary Inquiry Into the Need For a Federal Statute of Unfair Competition," 17 U. Dayton L. Rev. 385 (1992) and Lange, "Sensing the Constitution," 17 U. Dayton L. Rev. 367 (1992).

7. The "sweat of the brow" theory of originality had relied partly on US copyright decisions which had said that if a work owed its origin to a particular individual or firm and not been copied from another work, that person or firm could be considered the work's author and partly on an economic incentives argument which posited that unless copyright protection was available for "low authorship" fact compilations, insufficient incentives would exist to engage in such socially beneficial conduct. See Ginsburg, "Creation and Commercial Value: Copyright Protection of Works of Information," 90 Colum. L. Rev. 1865 (1990). Two other important pre-Feist articles on copyright in fact compilations are: Gorman, "Fact or Fancy: The Implications For Copyright," 29 J. Copyright Soc'y 560 (1982) and DeNicola, "Copyright In Collections of Fact: A Theory for the Protection of Facts," 81 Colum. L. Rev. 516 (1981). 
focused on its elevation of originality to a constitutional mandate. ${ }^{8}$ Even though there was a perfectly adequate statutory ground for the decision, the Court-not once, but numerous times-indicated that it believed that Congress lacks power to amend the copyright statute to provide protection to data compilations unable to pass a creativitybased originality standard. 9

Professor Ginsburg has directly challenged the Court's constitutional interpretation. ${ }^{10}$ A number of scholars has sought to resolve the constitutional challenge posed by Feist by asserting that the commerce clause would provide a sufficient basis for Congress to legislate a "fix" to the problem of potentially too little protection for unoriginal data compilations that may have been opened up by Feist. ${ }^{11}$ Despite the initial panic in some circles about the implications of Feist, 12 Congress has yet to consider any sort of legislative change for unoriginal data compilations, either by calling the Supreme Court's bluff and amending copyright law to adopt the "sweat of the brow" theory of originality or by enacting an equivalent to the proposed EC direc-

8. The Court could have decided that Rural's white pages listings did not meet the originality criterion that Congress had put in the Copyright Act of 1976, 17 U.S.C. $\$ 101$ (definition of "compilation") which requires creativity in selection or arrangement of data. The Court went on, however, to say that originality of a higher sort than the independent creation standard on which "sweat of the brow" copyrights have depended was constitutionally mandated under Art. I, §8, cl. 8 of the U.S. Constitution (granting Congress power to promote the progress of science by enacting legislation to give a limited period of exclusive rights to authors for their writings). Feist, 111 S.Ct. at 1288. The critics of Feist's constitutionalism have chiefly focused on economic reasons why Congress ought to be free to consider extending copyright protection for "sweat of the brow" data compilations. See, e.g., Ginsburg, supra n. 5 and Heald, supra n. 5.

9. See Goldstein, "Copyright," 38 J. Copyright Soc'y 109, 119 (1991) (noting that the Feist opinion declares that originality is a constitutional mandate "no fewer than thirteen times").

10. See Ginsburg, supra n. 5.

11. Id. at 365-71. Congress mainly relied on the commerce clause for power to enact the Semiconductor Chip Protection Act, 17 U.S.C. § 901 et seq. (1988), after questions were raised about its power to act under Art. I, \$8, cl. 8 because semiconductor designs were, in the view of some, neither writings of authors nor discoveries of inventors. See Kastenmeier \& Remington, "The Semiconductor Chip Protection Act of 1984: Swamp or Firm Ground?," 70 Minn. L. Rev. 417, 420-24 (1985) (discussing the constitutional basis for SCPA). Oddly enough, Feist may inadvertently have reopened constitutional questions about SCPA because of its reliance on The Trademark Cases, 100 U.S. 82 (1879) (striking down as unconstitutional a federal trademark statute that Congress had thought was authorized under the commerce clause or Art. I, §8, cl. 8). Of course, the commerce clause powers of Congress have expanded dramatically since 1879, so perhaps The Trademark Cases no longer present any meaningful limit on Congress' power to enact intellectual property legislation. See Dreyfuss, supra n. 5 (urging adoption of a broad-based unified intellectual property regime).

12. The U.S. Register of Copyright characterized Feist as having "dropped a bomb" on U.S. copyright law. See Litman, "After Feist," 17 U. Dayton L. Rev. 607, 607 (1992). 
tive for computer databases. ${ }^{13}$ Most data compilers and their copyright counsel seem content for the moment to see how much protection they can still obtain from U.S. copyright law. ${ }^{14}$ Database firms may also be relying more on contractual or technological restrictions on access to and use of unoriginal (or otherwise uncopyrightable) "literary works".15

Section I of this report will discuss the impact that Feist has had on the outcome and analysis in copyright decisions involving fact works. ${ }^{16}$ As one might expect in the aftermath of Feist, courts have rejected copyright claims for such works unless some creativity in selection or arrangement of data could be identified. ${ }^{17}$ Even when fact works have been able to pass the originality hurdle and been found eligible for copyright protection, courts have also tended to follow Feist's lead by treating fact compilations as having a "thin" (although not necessarily "anorexic" ${ }^{18}$ ) scope of copyright protection. ${ }^{19}$ Section I will show how Feist's broad ranging analysis of copyright's originality standard has opened up a number of new avenues for originality analysis. Some of these avenues may prove to be dead ends; others, however, are likely to become major thoroughfares. Section II will discuss emerging originality issues in software copyright cases, as well as some foreseeable originality issues posed by new digital media products.

13. See Commission of the European Communities, Proposal for a Council Directive on the Legal Protection of Databases (1992).

14. See, e.g., Sheils \& Penchina, "What's All The Fuss About Feist? The Sky Is Not Falling on the Intellectual Property Rights of Online Database Proprietors," $17 U$. Dayton L. Rev. 563 (1992). But see infra nn, 128-30 and accompanying text.

15. See, e.g., Litman, supra n. 12, at 611-12 and Reichman, "Electronic Information Tools: The Outer Edge of World Intellectual Property Law," 17 U. Dayton L. Rev. 797, 820-30 (1992).

16. Feist has, of course, had an impact on cases involving other kinds of copyrighted works as well. Maps, for example, are classified as pictorial or graphic works, but have substantial factual components so that the principles of Feist apply to them as well. See, e.g., Mason v. Montgomery Data, Inc., 967 F.2d 135 (5th Cir 1992) (ruling Mason's maps were copyrightable because of originality in selection and arrangement of information in them). Feist has been influential in a broad range of other cases as well. See, e.g., Those Characters From Cleveland, Inc. v. J.J. Gams, Inc., 23 U.S.P.Q.2d (BNA) 1109 (S.D.N.Y. 1992) (involving grotesque toys) and Cable Network News, Inc. v. Video Monitoring Services of America, Inc., 940 F.2d 1471 (11th Cir. 1991), vacated, 949 F.2d 378, on rehearing 959 F.2d 188 (1992) (involving video segments of cable news program).

17. See, e.g., Sinai v. Bureau of Automotive Repair, 25 U.S.P.Q.2d (BNA) 1809 (N.D. Cal. 1992) (granting summary judgment to defendant because of insufficient creativity in auto emission control system information chart).

18. Key Publications, Inc. v. Chinatown Today Pub'g Enterprises, Inc., 945 F.2d 509,514 (2d Cir. 1991) (indicating that copyright for compilations is thin but not anorexic). Key is discussed infra nn. 62-64 and accompanying text.

19. Feist, 111 S.Ct. at 1289 . See, e.g., Kregos v. Associated Press, 795 F. Supp. 1325 (S.D.N.Y. 1992) (AP's variations on Kregos's baseball pitching form sufficed to avoid infringement). Kregos is discussed infra $\mathrm{nn}$. 72-80 and accompanying text. 


\section{The Impact of Fetst on Fact Work Cases}

The most evident impact of Feist on the U.S. caselaw concerning the originality standard for literary works has been to undercut as viable precedents a number of cases that had grounded themselves in the "sweat of the brow" theory of originality. ${ }^{20}$ Feist has also disabled the making of direct policy-based arguments about the need to provide copyright protection for a fact work or its factual content in order to provide adequate investment incentives to those who prepare them. ${ }^{21}$ Works that Professor Ginsburg had sought to characterize as "works of low authorship"22 must, in the aftermath of Feist, be regarded as "works of no authorship," although perhaps the "low authorship" term will live on in the caselaw according a thin scope of protection to those fact works that have just barely made it over the originality threshold required by Feist. ${ }^{23}$

No longer is it a bad thing to have relied on someone else's research efforts and saved oneself some time, money and energy in the process. ${ }^{24}$ In what has already become among the most commonly quoted passages from Feist, ${ }^{25}$ the Court stated:

It may seem unfair that much of the fruit of a compiler's labor may be used by others without compensation. As Justice Brennan has correctly observed, however, this is not "some unforeseen byproduct of a statutory scheme." It is, rather, "the essence of copyright", and a constitutional requirement. The primary objective of copyright is not to reward the labor of authors, but "[t]o promote the Progress of Science and Useful Arts.” Art. I, §8, cl. 8....To this end, copyright assures authors the right to their original expression, but encour-

20. Cases explicitly criticized in Feist for their "sweat of the brow" analysis were: Leon v. Pacific Telephone \& Telegraph Co., 91 F.2d 484 (9th Cir. 1937) and Jeweler's Circular Pub'g Co., 281 F. 83 (2d Cir. 1922). In addition to the other telephone directory white pages cases, a number of other cases are unlikely to survive as precedents. See, e.g., Rand McNally \& Co. v. Fleet Management System, 634 F. Supp. 604 (N.D. Ill. 1986) (copying of mileage data from map held to be copyright infringment). Because of Feist's extensive reliance in on the copyright analysis in Patterson \& Joyce, "Monopolizing The Law: The Scope of Copyright Protection For Law Reports and Statutory Compilations," 36 UCLA L. Rev. 719 (1989), Feist may also undermine the viability of cases such as West Pub. Co. v. Mead Data Central, Inc., 799 F.2d 1219 (8th Cir. 1986) (pre-Feist case in which star pagination feature was ruled infringing as an expression of West's arrangement of judicial opinions in law books).

21. See, e.g., Sinai, 25 U.S.P.Q.2d 1809 (rejecting a post-Feist sweat of the brow argument).

22. Ginsburg, supra n. 7, at 1866 .

23. Although this term has been used (with attribution to Prof. Ginsburg) in the law review literature about Feist, see, e.g., Heald, supra n. 5, at 150, it has not as yet been adopted in the caselaw.

24. See, e.g., Adventures in Good Eating, Inc. v. Best Places To Eat, Inc., 131 F.2d 809, 812 (7th Cir. 1942) (second compiler must "start from scratch" and do his own work). 1992)

25. See, e.g., Sega Enterprises Ltd. v. Accolade, Inc., 977 F2d 1510, 1527 (9th Cir. 
ages others to build freely upon the ideas and information conveyed in a work. ${ }^{26}$

Far from being castigated as "chiseling for profit," 27 the second comer who uses someone else's research might today find him- or herself praised for fulfilling the constitutional purposes of copyright law.

The Court in Feist did leave open the possibility that unfair competition law might, at least in egregious situations such as those presented years ago in International News Service v. Associated Press, ${ }^{28}$ provide some remedy for malcompetitive copying of unoriginal fact compilations. ${ }^{29}$ The Court's oblique reference to unfair competition remedies in Feist ${ }^{30}$ has predictably re-ignited among academics a longstanding federal preemption debate about whether state law can constitutionally be used to protect uncopyrightable elements of writings such as facts. ${ }^{31}$

Some believe that federal copyright law should preempt such uses of state law unfair competition law because allowing others to freely copy facts is part of the Congressional and constitutional purpose for copyright law. ${ }^{32}$ Others seem willing to give state law some room to act in egregious cases (if only we could find some principled basis for figuring out what these are). ${ }^{33}$ If, however, the state of Kan-

26. Feist, 111 S.Ct. at $1289-90$.

27. Wainwright Securities v. Wall Street Transcript Corp., 558 F.2d 91, 97 (2d Cir. 1977), cert. denied, 434 U.S. 1014 (1978) (rejecting fair use defense for copying of key portions of lengthy research reports).

28. 248 U.S. 215 (1918) (INS held to have unlawfully misappropriated AP news from early editions of AP newspapers and public bulletin boards). INS is cited in Feist principally in support of two propositions: that copyright law does not permit protection of "sweat of the brow" elements of protected works and that news in a copyrighted newspaper is unprotectable by copyright law. Feist, $111 \mathrm{~S} . C \mathrm{t}$. at 1292 . In a footnote, the Court observes that INS was decided "on noncopyright grounds that are not relevant here." Id. at 1292, n.8. The Court did not seem to recognize the irony of quoting INS for the position that copyright does not permit protection of facts when INS treated AP as having property in facts on non-copyright grounds. In other cases, the Supreme Court has cited INS as supporting recognition of property rights in facts. See, e.g., Carpenter v. U.S., 484 U.S. 19 (1987). For a critique of Carpenter's use of INS, see, e.g., Samuelson, "Information As Property: Do Ruckelshaus and Carpenter Signal a Changing Direction in Intellectual Property Law," 38 Cath. U. L. Rev. 365, 387-98 (1989).

29. See Gordon, "On Owning Information: Intellectual Property and the Restitutionary Impulse," $78 \mathrm{Va}$. L. Rev. 149, 165, 266-73 (1992) (discussing INS as a "malcompetitive" copying case).

30. Feist, 111 S.Ct. at 1292 (citing authorities concerning the availability of unfair competition protection for sweat of the brow works).

31. See, e.g., Gordon, supra n. 29, at 154-55, n. 21-22 (discussing differences of scholarly opinion concerning federal preemption of state law as to matters excluded from the scope of copyright by 17 USC $\$ 102(b)$ such as facts). See also Abrams, supra n. 5, at 35-39.

32. See, e.g., Abrams, "Copyright, Misappropriation, and Preemption: Constitutional and Statutory Limits of State Law Protection," 1983 Sup. Ct. Rev. 509 (1983).

33. See, e.g., American Law Institute, Restatement of the Law of Unfair Competition 1-11(Tent. Dr. No. 4 1993) (endorsing misappropriation doctrine in appropriate cases). See also, Gordon, supra n. 29, at 221-58 (proposing a set of minimum constraints for establishing misappropriation). 
sas had reacted to Feist by passing a data compilation piracy law outlawing the very kind of copying Feist did from Rural's directory, I believe that the Court would have no difficulty in striking down this state action for being inconsistent with federal copyright policy. I believe the same would be true if Kansas courts interpreted that state's unfair competition law as outlawing Feist's conduct.

The principal rationale given in Feist as to why facts are not protectable by copyright law was that facts are not "original" to any author, but are rather "discovered" by authors. ${ }^{34}$ Because section 102(b) of the Copyright Act of 1976 states that no copyright protection is available for "discoveries" embodied in a copyrighted work, ${ }^{35}$ the Court regarded facts as unprotectable under section $102(\mathrm{~b}){ }^{36}$

The epistemology underlying the assertion that facts are "discovered" rather than being "authored" is debatable. ${ }^{37}$ Yet a number of courts have made use of this rationale in rejecting copyright claims for certain facts, or clusters of facts, in post-Feist cases. ${ }^{38}$ When a defendant copied what turned out to be false facts, one court extended the rationale of Feist to hold that this copying was no more copyright infringement than if the facts had been as true as the defendant thought they were. ${ }^{39}$ However, another court regarded newly generated facts as protectable by copyright because they originated with the plaintiff. Only preexisting facts in the same compilation were regarded as unoriginal and unprotectable by copyright. ${ }^{40}$

The discovery rationale for rejecting copyright protection in facts has led to some difficulties in drawing boundary lines between facts which the Court has insisted are discovered and opinions which are arguably more original to authors and, therefore, more potentially reflective of that minimal spark of creativity or judgment necessary to

34. Feist, 111 S.Ct. at 1288.

35. 17 U.S.C. $\$ 102$ (b) (1988).

36. Feist, 111 S.Ct. at $1293-95$.

37. See, e.g., Gordon, supra n. 5, at 93-96. See also Ginsburg, "Sabotaging and Reconstructing History: A Comment on the Scope of Copyright Protection in Works of History After Hoehling v. Universal City Studios," 29 J. Copyright Soc'y 647, 658 (1982).

38. See, e.g., Arica Institute, Inc. v. Palmer, 970 F.2d 1067 (2d Cir. 1992) (holding the plaintiff to statements in its literature that described a particular sequence of ego fixations as an unalterable law of nature that the founder had discovered; because of this, it was unprotectable by copyright law)

39. See Nester's Map \& Guide Corp. v. Hagstrom Map Co., 796 F.2d 729, 733 (E.D.N.Y. 1992) ("To treat 'false' facts interspersed among actual facts as fiction would mean that no one could ever reproduce or copy actual facts without the risk of reproducing a false fact and thereby violating a copyright.")

40. See Corsearch v. Thomson \& Thomson, 792 F. Supp. 305, 322 (S.D.N.Y. 1992). ("T\&T's copyright extends to its internally generated information and to its particular enhancements to the items of information collected from the state trademark records, not to the items of information themselves collected from the states.") The court in this case did not treat internally generated information as having been "discovered" by the plaintiffs. 
support copyright protection. ${ }^{41}$ In NADA Services Corp. v. CCC Information Services, Inc., ${ }^{42}$ for example, the court seemed to give some credence to NADA's argument that the used car prices NADA had included in its "Official Used Car Guide" met the originality requirement because of the judgment NADA personnel exercised in deciding what prices to quote for each car in the guide. ${ }^{43}$

Feist's linkage of the originality standard and section 102(b)'s exclusion from protection of discoveries was not really necessary to its ruling. The Court might instead have grounded its rejection of copyright protection for facts on the basis Professor Litman has suggested. She reminds us that society has long regarded facts as "basic building blocks...of expression; of self-government; and of knowledge itself. Depriving the public at large of the unfettered use of those building blocks could frustrate the growth of learning, impede the marketplace of ideas, and impoverish public discourse." 44 Many cases could have been cited to support this rationale for saying that facts are unprotectable by copyright law, including some cited by Feist. ${ }^{45}$

The linkage of section 102(b)'s exclusion of discoveries to originality considerations in Feist has had a noticeable impact on the subsequent caselaw. It has, for example, become much more common for parties to argue, and even sometimes for courts to decide, that certain aspects of copyrighted works that are unprotectable under section 102(b) do not meet copyright's originality standard either, and hence the copying of them is noninfringing. ${ }^{4} 6$

Feist's linkage of originality and excludable subject matters under section 102(b) may be particularly important in cases involving functional writings. To understand why this might be so, it is well to begin with the text of section 102(b): "In no case does copyright protection for an original work of authorship extend to any idea, proce-

41. Feist, 111 S.Ct. at 1287 (requisite creativity level is "extremely low").

42. 1991 W.L. 287961 (N.D. Ill 1991).

43. The court found the evidence on the question of minimal creativity to be mixed. NADA personnel were not trained in used car assessments, nor did NADA have guidelines for them. Much of the work involved averaging statistics. Yet the court perceived that some judgment, as well as some intellectual labor, was required to decide what price to report in the NADA Guide for each car. The court ultimately, however, denied NADA's request for a preliminary injunction.

44. Litman, supra n. 12 , at $613-14$.

45. See, e.g., Miller v. Universal City Studios, Inc., 650 F.2d 1365, 1371 (5th Cir. 1981). There are places in Feist where this rationale shows through. Feist, 111 S.Ct. at 1290,1292 .

46. This has been especially true in the software copyright caselaw, see infra Section II-A. See also Arica Institute, Inc. v. Palmer, 1991 Cop. L. Rptr (CCH) I26,712 (S.D.N.Y. 1991), affd, 970 F.2d 1067 (2d Cir. 1992) (trial court ruled that Arica's arrangement of words were constituent parts of the group's "system" for categorizing personality types; appellate court affirmed on the ground that the arrangement of words was unprotectable because Arica had claimed the words and their arrangement reflected a law of nature that the founder had discovered). 
dure, process, system, method of operation, concept, principle, or discovery, regardless of the form in which it is described, explained, illustrated, or embodied in such work." 47 In its exclusion of procedures, processes, systems and methods of operation, this provision codifies a longstanding principle of U.S. copyright law deriving from a century-old U.S. Supreme Court case, Baker v. Selden. ${ }^{48}$

The Court in that case ruled that Baker did not infringe the copyright in Selden's book because although the sample ledger sheets in his book were substantially similar in the selection and arrangement of headings and columns to those found in Selden's book, the selection and arrangement were constituent elements of the accounting system and were beyond the scope of copyright protection available to the book. In subsequent cases, courts followed Baker v. Selden in ruling that other kinds of functional content depicted in copyrighted works, such as processes, procedures, systems, and methods of operation, were beyond the scope of copyright protection in the work. ${ }^{49}$

This provision also has relevance to fact compilation cases because fact compilations are often valuable because of the method or system used to arrange the information. Under the principles of Baker v. Selden and Feist, originality arising from the method or system does not confer copyright protection on the compilation which, because of the methodical arrangement, may lack the kind of "originality" necessary for copyright protection. Thus, if courts come to be consistent about taking section 102(b) seriously, Feist's linkage of originality and aspects of works that are unprotectable under 102(b) may have a very profound impact on the fact compilation caselaw. ${ }^{50}$

Feist has certainly caused courts to be more explicit about identifying the presence or absence of that minimal creative spark that is necessary to support a copyright in a fact work. Sometimes such a spark has been entirely lacking, as it was in Feist. ${ }^{51}$ However, except when the arrangement of facts has been constrained by external factors ${ }^{52}$ or is fairly standard for works of that kind, ${ }^{53}$ a creative spark

47. 17 U.S.C. $\$ 102(\mathrm{~b})(1988)$

48. 101 U.S. 99 (1879).

49. For a partial listing of the progeny of Baker v. Selden, see, e.g., Samuelson, "Computer Programs, User Interfaces, and Section 102(b) of the Copyright Act of 1976: A Critique of Lotus v. Paperback," 55 Law \& Contemp. Prob. 311, 324, n. 61 (1992).

50. As we review decisions relying on creativity in selection as a basis for a finding of sufficient originality, it will become clear why section 102(b) presents problems for the justification of copyright in some fact compilations.

51. See, e.g., Project Dev. Group v. O.H. Materials Corp., 766 F. Supp. 1348 (W.D. $\mathrm{Pa}$. 1991) (bid proposal materials held uncopyrightable).

52. See, e.g., Sinai, 25 U.S.P.Q.2d 1809 (externalities arising from requirements of California emissions control laws).

53. See, e.g., Victor Lalli Enterprises, Inc. v. Big Red Apple, Inc., 936 F.2d 671 (2d Cir. 1991) (horse racing charts using a conventional grid did not satisfy the originality standard). 
has generally been easy for courts to find, especially in fact arrangement cases. 54

Creativity in selection has sometimes been more troublesome in the post-Feist caselaw. ${ }^{55}$ In a now vacated and reversed decision in Bellsouth Advertising \& Pub. Co. v. Donnelley Information Pub., ${ }^{56}$ the Eleventh Circuit Court of Appeals had seemed to take at face value Bellsouth's assertion that creativity in selection could be satisfied by judgments as deciding on the geographical boundaries for a yellow pages directory, the closing date for that year's compilation, and the number of free listings to permit. ${ }^{57}$ As the Eleventh Circuit came to realize, it is difficult to justify these as creative selections under Feist, for Rural engaged in similar selections. ${ }^{58}$ The court was on firmer ground in finding creativity in Bellsouth's selection of categories to be listed in the directory. ${ }^{59}$ The chief problem for Bellsouth's case was that the wily defendant had renamed many categories in its directory, ${ }^{60}$ leaving the court with the dilemma of how much nonliteral protection to give to Bellsouth's directory. After lengthy reconsideration of the case, the Eleventh Circuit ultimately determined that Donnelley had only copied facts from Bellsouth's directories. ${ }^{61}$

54. See, e.g., Budish v. Gordon, 784 F. Supp. 1320 (N.D. Ohio 1992) (originality in selection and arrangment supported copyright protection for tables of information in book on Medicaid planning).

55. For an example of an untroublesome creativity-in-selection case, see, e.g., U.S. Payphone, Inc. v. Executives Unlimited of Durham, Inc., 931 F.2d 888 (4th Cir. 1991) (selection of state tariff information concerning telephone utilities).

56. 719 F. Supp. 1551 (S.D. Fla. 1988), affd 933 F.2d 952 (11th Cir. 1991), vacated 977 F.2d 1435 (11th Cir. 1992), rev'd 999 F.2d 1436 (11th Cir. 1993).

57. See Bellsouth, 933 F.2d at 958 . See also Bellsouth, 719 F. Supp. at 1557-58, . The court's coordination theory (coordinating the name of the business with its address and telephone number) was likewise suspect under Feist. Bellsouth, 933 F.2d at $957-58$.

58. Bellsouth, 999 F.2d 1436 (ruling that acts of selection on which trial court relied were not acts of authorship).

59. Bellsouth, 933 F.2d at 958.

60. The first appellate Bellsouth opinion was not explicit about how much renaming had occurred. A majority of the court has since ruled that there was sufficient renaming of categories to render similarities noninfringing, but it too offers little detail about the degree of overlap and difference. Bellsouth, $999 \mathrm{~F} .2 \mathrm{~d}$ at 1443-46. The court does suggest that there were significant functional constraints on the naming of some categories. Id. at 1443 . The research literature suggests that there is often more room for variation in categorization for such things as yellow pages directories than people might expect. See, e.g., Furnas, Landauer, Gomez, \& Dumais, "Statistical Semantics: Analysis of the Potential Performance of Keyword Information Systems," 62 Bell. Sys. Tech. J. 1753 (1983) and Furnas, Landauer, Gomez, \& Dumais, "The Vocabulary Problem in Human System Communication," 30 Comm. ACM 964 (1987).

61. Bellsouth, 999 F.2d 1436 (ordering entry of summary judgment in Donnelley's favor). One very strange proposition discussed in the Eleventh Circuit's first Bellsouth decision was that a finding of infringement might be justified because Donnelley could have reproduced Bellsouth's copyrighted compilation if it had chosen to do so. Bellsouth, 933 F.2d at 959 . The capacity to infringe was possible because Donnelley's database of information from Bellsouth's yellow pages included codes repre- 
Creativity in selection was also analyzed in Key Publications, Inc. v Chinatown Today Publishing Enterprises, Inc., ${ }^{62}$ another postFeist fact compilation case. Although about seventy-five per cent of the listings in the defendant's yellow pages directory for ChineseAmerican businesses in New York overlapped with listings in the plaintiff's competing directory, the Second Circuit reversed a finding of infringement because Key's directory had 260 categories of listings whereas Chinatown's had only 28 categories, of which only three overlapped with Key's. The court gave no weight to similarities in listings within categories. "The arrangement of categories in a directory is to be distinguished from the placement of a listing in a particular category. Placing listings within categories is the sort of mechanical task that does not merit copyright protection."63 The critical issue, said the court, was "not whether there is overlap or copying but whether the organizing principle guiding the selection of businesses for the two publications is in fact substantially similar."64 Having found substantial differences in the organizing principles used by the parties, the court decided no infringement had occurred.

A number of cases have followed Key's "organizing principle" approach to judging creativity in selection. ${ }^{65}$ In Warren Publishing, Inc. $v$ Microdos Data Corp., ${ }^{66}$ for example, the court found sufficient originality in a cable system directory in part because of creativity in selection arising from Warren's development of "a system for selecting communities which is original in the industry. The selection pro-

senting Bellsouth's categories. Enjoining use of a database because it gives a user an unexercised ability to infringe is a rather radical-although not unprecedentedidea. See also West Pub. Co. v. Mead Data Central, Inc., 799 F.2d 1219, 1227 (8th Cir. 1986) (expressing concern that users of Lexis could use the star pagination feature of Lexis to recreate West's arrangement of cases in its copyrighted volumes if they chose to do so, even though it would be uneconomical to do so). It was especially radical as applied to this case given that Donnelly's incentive to use the database to make an infringing copy of the Bellsouth directory would seem to be very small. Any such copy could only undo the careful efforts Donnelley had made to reproduce only the data from Bellsouth's compilation.

The potential for facilitating infringement was argued as a basis of liability in Sony Corp. of America v. Universal City Studios, Inc., 464 U.S. 417 (1984). The Supreme Court ruled that Sony's sale of a device that had substantial noninfringing uses could not be enjoined as a contributory infringement. In Sony, though, it was apparent that the public wanted to use videotape recorders to make unauthorized copies of copyrighted works. When a new technology poses a question to which copyright law does not have a certain answer, Sony directs that courts should construe the law in light of its underlying purposes. Sony, 464 U.S. at 432 . It would be consistent with Sony to have ruled that an unexercised potential for infringement where there is no incentive to infringe should be enjoined.

62. 945 F.2d 509 (2d Cir. 1991).

63. Id at 515 .

64. Id.

65. See, e.g., Nester's Map \& Guide Corp v. Hagstrom Map Co., 796 F. Supp. 729 (E.D.N.Y. 1992) (copyright in taxi guide to New York City infringed because of similarities in selection).

66. 1992 Cop. L. Dec. (CCH) $\llbracket 26,928$ (N.D. Ga. 1992). 
cess represents a part of the format of the compilation which is copyrightable." ${ }^{27}$ Competing directories contained different numbers of cable community listings for particular states because they used different definitions of cable communities than Warren had. ${ }^{68}$

The major problem with the "organizing principle" approach suggested in Key and applied in Warren is that the courts have not even addressed the question of whether this approach comports with principles of copyright law embodied in section 102(b). The organizing principle for Selden's ledger sheets was original to him. However, that didn't make Baker's use of substantially similar ledger sheets in his own book an infringement of Selden's copyright.69 That the organizing principle for arrangement of words in the ledger sheets in Baker's and Selden's books was the same meant that the works shared a common idea, namely, implementation of the same accounting system. Before courts make further use of Key's "organizing principle" or Warren's "system" theory of originality in fact compilation cases, they should inquire whether this approach is consistent with the Baker v Selden tradition of U.S. law which is now embodied in section 102(b). ${ }^{70}$ One can also question whether Warren can be reconciled with Feist, for the court in that case suggested that creativity in the definition of a term can suffice to make a whole directory constructed around it protectable by copyright law, a proposition it is far from clear the Supreme Court would accept. The Eleventh Circuit's recent Bellsouth decision indicates that creativity in the means one uses for selecting or arranging data is not necessarily an act of authorship. ${ }^{71}$

The Second Circuit Court of Appeals was more attentive to the potential for conflict between section 102(b)'s exclusions of methods and the desire of a plaintiff to claim copyright because of creativity in the selection and arrangement of categories of information in Kregos v. Associated Press. ${ }^{72}$ Kregos had developed a baseball pitching form consisting of four categories of information about a particular day's game (the team name, the starting pitcher, the game time and the betting odds) along with nine categories of information about that day's pitcher grouped in three categories. Concerning the pitcher's performance during the whole season, Kregos included in his form (1) the pitcher's won/lost record, and (2) his earned run average. Concerning his performance for the season against the opposing team at that site, Kregos included (3) the pitcher's won/lost record, (4) the number of innings he pitched, and (5) his earned run average. For

67. Id. at 25,392 .

68. Id. at $25,390-93$.

69. See supra $\mathrm{nn}$. 48-50 and accompanying text.

70. See, e.g., Samuelson, supra n. 49 , at 311 .

71. See, e.g., Bellsouth, 999 F.2d at 1441-46.

72. 937 F.2d 700 (2d Cir. 1991). 
the pitcher's last three starts, (6) his won/lost record, (7) the number of innings he pitched, (8) his earned run average, and (9) his men-onbase average. ${ }^{73}$ Although many baseball forms had existed in the past, no one but Kregos had ever used this particular set of nine items arranged in this manner.

The Associated Press copied Kregos's form, at first nearly exactly, and then with some variations. AP sought summary judgment on three grounds: (1) insufficient originality in expression to support a copyright, (2) idea/expression merger because of limited possibilities for variation in expression, ${ }^{74}$ and (3) exclusion from protection under Baker v Selden's "blank form" rule. ${ }^{75}$ The trial court granted summary judgment to AP. The Second Circuit, in a split decision, reversed.

The main difference between the appellate court majority opinion, on the one hand, and the trial court and the dissenting appellate opinions, on the other hand, concerned whether Kregos's selection and arrangement of these categories of data was reflective of a method Kregos had developed for predicting the outcomes of baseball games. ${ }^{76}$ The majority opinion agreed that if it was, Kregos would not be able to get copyright protection for his form under principles deriving from Baker v. Selden. ${ }^{77}$ Although agreeing that Kregos was implicitly indicating that "his selections have some utility in predicting outcomes," the majority went on to say that Kregos "has not gone so far as to provide a system for weighing the combined value of the nine characteristics for each of the two opposing pitchers and determining a probability as to which is more likely to win." ${ }^{78}$ As long as

73. Id. at 702 .

74. U.S. copyright law has long accepted the principle that there may be such a limited number of ways that a particular idea can be expressed that it would frustrate the principle that ideas are unprotectable to protect the limited variations. See, e.g., Baker v. Selden, 101 U.S. 99 (1879) (arrangement of headings and columns was incident to unprotectable bookkeeping system) and Morrissey v. Proctor \& Gamble Co., 349 F.2d 67 (1st Cir. 1967) (only limited variations possible in sweepstakes rules).

75. Cases following Baker $v$. Selden have ruled that blank forms are uncopyrightable. See, e.g., Bibbero Systems, Inc. v. Colwell Systems, Inc., 893 F.2d 1104 (9th Cir. 1990).

76. Compare Kregos, 937 F.2d at 705-707 with the partially dissenting opinion of Judge Sweet, id. at 711-716 and Kregos v. Associated Press, 731 F. Supp. 113 (S.D.N.Y. 1990).

77. Id. at 706-07. See supra nn. 48-50 and accompanying text for a discussion of Baker v. Selden.

78. Id. at 706. Although in this statement, the court seems to interpret section 102(b)'s exclusion of "systems" as limited to systems so tightly constructed as to be virtually mechanical, it goes on to express doubt that a doctor could get copyright protection for a compilation of symptoms that the doctor thinks might suggest the presence of a particular disease even if the doctor did not claim it to be a surefire predictor of presence of the disease, but only an expression of his or her opinion. Id. at 707. Yet, this is not so different from what Kregos had done. This suggests that it was Kregos' incentive-based argument that carried the day, for a doctor would be compensated for his or her loosely predictive method by fees charged to patients, whereas all Kregos could hope for was license fees from newspapers. 
selections of facts "involve matters of taste and personal opinion," said the court, "there is no serious risk that withholding the merger doctrine will extend protection to an idea."79

It may be that Kregos's lawyer had advised him to characterize the form as expressive of his opinion and personal taste. If so, it was a successful strategem. ${ }^{80}$ Certainly, in the aftermath of Kregos, one can expect other data compilers to understate any systematic or methodical elements to their form. As long as one claims that the form selects or arranges information according to one's own personal taste, one may be able to claim copyright in it, at least in the Second Circuit. Perhaps baseball forms will prove to be a special situation. In many instances, it would be ludicrous to assert that an arrangement of information on a form was an expression of one's personal taste. In general, claims for copyright protection in business forms have continued to be rejected in US caselaw except when and to the extent that textual explanations also appear on the form. ${ }^{81}$

A pernicious trend to which Kregos has contributed is the use of raw multiplication to indicate the possible range of different selections or arrangements of factual information, which courts sometimes use to indicate the degree of originality of the compilation. Id. at 704. This ignores, among other things, that random arrangements are not protectable by copyright law, see, e.g., Toro Co. v. R\&R Products Co., 787 F.2d 1208 (8th Cir. 1986), nor are methodical arrangements, see, e.g., Baker v. Selden, 101 U.S. 99 (1879). See, e.g., Coates-Freeman Associates, Inc. v. Polaroid Corp., 792 F. Supp. 879, 883-84 (D. Mass. 1992) (court multiplied number of possible combinations and even explained the mathematical means that the Second Circuit must have used to reach the number of possibilities in Kregos). See also Lotus Dev. Corp. v. Borland Int'l, Inc., 831 F. Supp. 223 (D. Mass. 1993) (characterizing Lotus's arrangement of commands as quite expressive because of the large number of possible choices).

79. Id. at 707. In view of the distaste the Feist decision displays for incentivebased arguments for extending copyright, it is somewhat surprising that the Second Circuit in Kregos implicitly made such an argument when expressing concern that if merger doctrine is interpreted too liberally, there will be too little protection for fact compilations. Id. at 706 .

Although I have no quarrel with the creativity of selection theory supporting a copyright in a social register of prominent families in New York, see Social Register Ass'n v. Murphy, 128 F. 116 (D. R.I. 1904), I do have some question about the creativity in selection theory used in Eckes v. Card Prices Update, Inc., 736 F.2d 859 (2d Cir. 1984). Although it is true that Eckes had selected 5000 baseball cards for inclusion in his compilation of "premium cards," it appears that the principal-if not the soleselection principle used for the "premium card" compilation pertained to the market value of the cards. Eckes obtained information on the price of such cards by a nationwide survey of baseball card dealers. Id. at 860 . The court emphasizes how much hard work went into the survey and analysis. Id. Eckes was, of course, decided before Feist, but to the extent it upheld copyright in the premium card compilation because of the research that went into determining which cards were most valuable, it would not seem to be consistent with Feist.

80. On remand, AP was found to have made sufficient variations in its revised baseball form so as not to infringe Kregos' copyright. See Kregos, 795 F. Supp. 1325.

81. For examples of the post-Feist blank forms caselaw, see, e.g., Financial Control Associates, Inc. v. Equity Builders, Inc., 799 F. Supp. 1103 (D. Kan. 1992) (questioning validity of mortgage prepayment form but ruling no infringement in any event) and Project Development Group v. OH Materials Corp., 766 F. Supp. 1348 (W.D. Pa. 1991) (bid proposal not copyrightable). But see Mid America Title Co. v. 
As this section has shown, Feist has had a profound effect on the caselaw concerning the originality standard for literary works under U.S. copyright law. It has caused courts to be much more precise about identifying the creative elements in fact compilations and other works falling within the copyright statute's broad definition of literary works. Incentive-based arguments for protection are rarely made as directly as they once were, although concerns about incentives can nevertheless be detected in some post-Feist cases. ${ }^{82}$

The central battleground in the post-Feist caselaw has been over creativity in selection. Courts have sometimes used suspect rationales for upholding copyrights in fact compilations, especially when they have suggested that copyright protection exists on account of the originality of the organizing principle, system, or definition employed in constructing the compilation.

There is now a way for methodical compilations to be protected, for patents have begun to issue for methodical compilations of data in the US. ${ }^{83}$ This trend may become stronger if courts start enforcing the principles embodied in section 102(b) of the US copyright statute. Use of patents may take some of the pressure off the drive to use copyright to protect such compilations. It is, however, conceivable that the day will come when the US Congress will have to decide whether to adopt a sui generis solution for data compilations of the

Kirk, 23 U.S.P.Q.2d (BNA) 1538 (7th Cir. 1993) (reversing dismissal of copyright infringement claim in title insurance form and remanding for fact findings on whether creative selection was involved and how much variation was possible).

An important pre-Feist decision on the copyrightability of blank forms is the Ninth Circuit Court of Appeals decision in Bibbero Systems, Inc. v. Colwell Systems, Inc., 893 F.2d 1104 (9th Cir. 1990). In that case, the court rejected a largely incentivebased argument for copyright protection for a medical insurance claim form. Bibbero argued creativity in selection because its form "contained some of the possible categories of information but not others, thus indicating which information was important." Id. at 1107. The Ninth Circuit characterized this ruling as "potentially limitless." Id. All forms, said the court, "seek only certain information, and by their selection, convey that the information sought is important....The purpose of Bibbero's superbill is to record information. Until the superbill is filled out, it conveys no information about the patient, the patient's diagnosis, or the patient's treatment....The superbill is simply a blank form which gives doctors a convenient method for recording services performed. The fact that there is a great deal of printing on the face of the formbecause of many possible diagnoses and treatments-does not make the form any less blank." Id. at 1107-08. The court in Bibbero bemoaned the lack of coherence in the forms cases. To the extent that some of the forms cases, notably Harcourt, Brace \& World, Inc. v. Graphic Controls, Inc., 329 F. Supp. 517 (S.D.N.Y. 1971), contravened principles of Baker v. Selden, 101 U.S. 99 (1879), the Ninth Circuit declined to follow them. Bibbero, 893 F.2d at 1107 . But see Kregos, 937 F.2d at 709 (critical of Bibbero). Bibbero's strength as a precedent can only have been enhanced by Feist.

82. See, e.g., Kregos, 937 F.2d 700.

83. See, e.g., Chisum, "The Patentability of Algorithms," 47 U. Pitt. L. Rev. 959, 1021-22 (1986) (giving examples). See also U.S. Patent No. 4,675,830 (1987) (claims for a method for producing data useful for constructing scalable fonts, as well as a product-by-process claim for the data compilation itself). 
sort now under consideration in the European Community, ${ }^{84}$ or for methodically selected or arranged data compilations that will tend to be incremental innovations rather than inventive works. ${ }^{85}$

\section{The Impact of Feist on the Originality of Computer Programs and Other Works in Digital Form}

\section{A. Originality Issues in Computer Program Cases}

Computer programs are frequently characterized in the American copyright caselaw as "literary works." 86 Although some cases seem to speak of programs as though they were the same manner of work as a novel by Ernest Hemingway, ${ }^{87}$ the trend in recent cases has been to recognize that even though programs may contain some elements of personal style, these works are highly functional in nature. ${ }^{88}$ Often they also contain factual elements as well. ${ }^{89}$ They may, therefore, be more akin to the kind of "literary work" involved in Baker v. Selden than to Hemingway novels. ${ }^{90}$

Functional writings, such as Selden's accounting book and computer programs, have historically been given a narrow scope of protection in the U.S. caselaw. ${ }^{91}$ The originality of the functional content embodied in such works, such as the accounting system re-

84. See Proposed Directive, supra n. 13. See also infra nn. 128-30 and accompanying text for a discussion of reasons that the U.S. may find it necessary to adopt such a sui generis system of protection for databases.

85. See Reichman, supra nn. 15, at 797-801.

86. See, e.g., Whelan Associates, Inc. v. Jaslow Dental Labs, Inc., 797 F.2d 1222, 1234 (3d Cir. 1986), cert. denied, 479 U.S. 1031 (1987).

87. See, e.g., Apple Computer, Inc. v. Franklin Computer Corp., 714 F.2d 1240, 1249 (3d Cir. 1983) (characterizing programs and Hemingway novels as literary works). See also Lotus Dev. Corp. v. Paperback Int'l, Inc., 740 F. Supp. 39, 54, 60, 70 (D. Mass. 1991) (comparing protection of nonliteral elements of programs to protection of nonliteral elements of novels, plays, music and other fanciful works).

88. See, e.g., Computer Associates Int'l, Inc. v. Altai, Inc., 775 F. Supp. 544 (E.D.N.Y. 1991), affd, 982 F.2d 693, 704 (2d Cir. 1992) (referring to "the essentially utilitarian nature" of programs) and Sega Enterprises, Ltd. v. Accolade, Inc., 977 F.2d 1510, 1524-26 (9th Cir. 1992) (characterizing programs as functional works).

89. Expert system programs, for example, have knowledge base components that consist largely of factual material on which the processing components of the expert system will operate. See, e.g., David Waterman, A Guide To Expert Systems (1986).

90. See, e.g., Altai, 982 F.2d at 704 (Baker v. Selden is the "doctrinal starting point ${ }^{n}$ for cases involving utilitarian works such as computer programs) and Sega, 977 F.2d at 1524 (relying on Baker v. Selden as limiting protection for functional works such as computer programs).

91. See, e.g., Kepner-Tregoe, Inc. v. Carabio, 203 U.S.P.Q.(BNA) 124 (E.D. Mich. 1979). See also Paul Goldstein, Copyright: Principles, Law, and Practice, Vol. 1, 11617, 197 (1989); Reichman, supra n. 15, at 817-20; and "Last Frontier Conference Report on Copyright Protection of Computer Software," 30 Jurim. J. 15, 18-19 (copyright protection for functional writings is narrower than for artistic and fanciful works). But see Miller, "Copyright Protection for Computer Programs, Databases, and Computer-Generated Works: Is Anything New Since CONTU?," 106 Harv. L. Rev. 977, 985-88 (1993) (disputing the view that the functionality of programs should narrow the scope of copyright protection). 
flected in the ledger sheets implementing Selden's accounting system, has not sufficed to convert the functional content into copyrightprotectable expression. ${ }^{92}$ Rather, the work's functional content has been considered as among the work's "ideas."

Section 102(b)'s exclusion of processes, procedures, systems and methods of operation from the scope of copyright protection was adopted by Congress with a watchful eye toward computer programs. ${ }^{93}$ Concerns had been expressed at Congressional hearings that without a provision such as 102 (b), owners of copyrights in computer programs would try to claim copyright in the methods and processes used by programmers rather than just in the "writing" which was what Congress intended to protect. 94

Notwithstanding the enactment of section 102(b), owners of computer program copyrights have sometimes sought to protect "processes," "procedures," "systems," or "methods of operation" embodied in programs. By characterizing such program elements as components of the "structure, sequence, and organization" of programs (which are then likened to structural details of works of literature), ${ }^{95}$ plaintiffs in a number of software copyright lawsuits have

92. See, e.g., Synercom Technology, Inc. v. University Computing Co., 462 F. Supp. 1003, 1012 (N.D. Tex. 1978) (labor in conception distinguished from labor in expression). But see Paperback, 740 F. Supp. at 56 (asserting that copyright should protect the most creative aspects of computer programs and user interfaces which tend to lie in the conceptualization of them rather than in encoding them into program instructions). See Samuelson, supra n. 49, at 253-54 (criticizing this aspect of Paperback. Another deviant aspect of Paperback's discussion of originality issues was its many references to the obviousness or nonobviousness of various elements of Lotus's user interface. See, e.g., Paperback, 740 F. Supp. at 58, 65-66. One of the lessons of Baker $\mathrm{v}$ Selden is that the novelty or nonobviousness of a functional element embodied in a copyrighted work does not mean that element is protectable by copyright law. See Samuelson, supra n. 49, at 232-33, n. 100.

93. See H.R. Rep. No. 1476, 94th Cong., 2d Sess. 57 (1976), reprinted in 1976 U.S.C.C.A.N. 5659, 5670; S. Rep. No. 473, 94th Cong., 2d Sess. 54 (1976). Although section 102(b) clearly excludes the more abstract elements of copyrighted works, such as ideas, concepts, principles, and discoveries, from the scope of copyright protection available to those works, it does more than this. It also excludes from protection some valuable detailed elements that may be embodied in such works, such as processes, procedures, systems, and methods of operation (and their constituent parts) that may be described or implemented in them. Processes, procedures, systems and methods of operation (and their constituent elements) are protectable, if at all, by trade secrecy or patent law. See, e.g., Brief Amicus Curiae of Eleven Copyright Law Professors, Lotus Dev. Corp. v. Borland Int'l, Inc., Civ. No. 90-11662-K (D. Mass.) at 6-9 (constituent elements of systems not protectable by copyright law).

94. Concerning testimony expressing such concern, see Hearings on S. 597 Before the Senate Subcomm on Patents, Trademarks, and Copyrights of the Comm on the Judiciary, 90th Cong., 1st Sess. 197 (1967). Concerning Congress's expression of concern that copyright not be construed to protect methods in programs, see H.R. Rep. No. 1476,1976 U.S.C.C.A.N. at 5670.

95. See, e.g., Whelan, 797 F.2d at 1235-38 (seeming to regard all program "SSO" as protectable by copyright law and likening program "SSO" to nonliteral elements of novels and plays). See also Lotus Dev. Corp. v. Borland Int'l, Inc., 831 F. Supp. 223, 230-31 (D. Mass. 1993) (rejecting Borland's argument that the Lotus command hierarchy for its spreadsheet program was unprotectable as a fundamental part of the 
sought to override the prohibitions of section 102(b). Because originality in the structure of literary works has often regarded as expressive, 96 whereas originality of a method or procedure is not, much of the dispute about the scope of copyright protection for computer programs has come to focus on "originality" issues.

This trend would seem to further reinforce Feist's linkage of copyright's originality standard and copyright policies embodied in section 102(b). Feist may tend, over time, to limit the scope of copyright protection available to computer programs, for much of the argument for extending protection to various elements of programs has focused on the need to extend protection to provide adequate incentives for investment in program development. ${ }^{97}$

Before discussing the most contentious of the originality disputes in computer program cases, it is worth pointing out that there have been a number of very conventional applications of the originality standard in software cases. In Apple Computer, Inc. v Microsoft Corp., for example, the court rejected Apple's claim to some elements of the Macintosh user interface because they were derived from the work of a third party. ${ }^{98}$ Because these elements were not original to Apple, Apple could not claim them as infringements, even if Microsoft had copied these elements from Apple's program, rather than from the third party.

In Atari Games Corp. v Nintendo of America, Inc., ${ }^{99}$ the court rejected Nintendo's claim of copyright in certain bit sequences because they consisted of random numbers generated by a computer and resulted from computer calculations. In line with copyright cases in which random selection and mechanical calculation results had been ruled unoriginal for copyright purposes, ${ }^{100}$ the court decided that these elements of the programs were disqualified from copyright protection for failure to satisfy copyright's originality standard.

A number of courts have also rejected copyright claims for elements of computer programs that had become, if not standard, then

functionality of the macro system because "Gone With the Wind" could also be described as a system).

96. See, e.g., Sheldon v. Metro-Goldwyn Pictures Corp., 81 F.2d 49 (2d Cir. 1936) (copying of detailed sequences of incidents from novel into a motion picture was infringing).

97. See Whelan, 797 F.2d at 1237-38 (making an incentive-based argument for expansive copyright protection for computer programs). But see Altai, $982 \mathrm{~F} .2 \mathrm{~d}$ at 712 (rejecting incentive arguments as having a "corrosive" effect on fundamental tenets of copyright law). Among those who have predicted that Feist would tend to have a limiting effect on the scope of copyright protection for computer programs is Raskind, "Assessing the Impact of Feist," 17 U. Dayton L. Rev. 331, 339 (1992).

98. 799 F. Supp. 1006, 1034-35 (N.D. Cal. 1992) (file folder icon was unprotectable element of Apple's interface because it was original to another software developer).

99. 1993 U.S. Dist Lexis 11653 (N.D. Cal. 1993).

100. See, e.g., Toro, $787 \mathrm{~F} .2 \mathrm{~d} 1208$ (no originality in arbitrary selection or arrangement); Kregos, 937 F.2d 700 (no originality in methodical arrangement). 
relatively commonplace or otherwise to be expected for programs of that kind, thereby continuing extension of the "scenes á faire" doctrine beyond the work of literature realm. ${ }^{101}$ The Second Circuit Court of Appeals in its landmark Computer Associates Int'l, Inc. v Altai, Inc. ${ }^{102}$ decision has indicated that unoriginal elements of this sort should be "filtered out" of infringement analysis to ensure that infringement is based only on the copying of expressive elements of programs.

One of the most contentious disputes in the software copyright caselaw has been over the protectability of internal interface information in computer programs. Reproduction of this information may be necessary to permit a second program developer to achieve interoperability among programs or between programs and hardware. Plaintiffs have sometimes argued that interfaces are creative compilations of information or aspects of the structure, sequence, and organization of programs that are original to their developers who could have structured them in a multiplicity of ways. ${ }^{103}$ Before Feist, it was common to argue that such elements of programs were in need of protection to sustain the proper incentives for program development. ${ }^{104}$ After Feist, more emphasis has tended to be placed on creativity in the selection of interface elements of a particular program, although incentives arguments are sometimes integrated into the argument as well. ${ }^{105}$

The first case to discuss whether copyright protection existed for internal interfaces was Secure Services Technology, Inc. v Time \& Space Processing, Inc. ${ }^{106}$ The court rejected the infringement claim because what SST was trying to protect failed to satisfy copyright's originality standard. SST was the manufacturer of a fax machine for transmitting classified information. TSP's ability to compete in this market depended on its machines being able to interoperate with SST machines. SST's machines contained software that implemented a standard protocol, but with certain variations permitted by the protocol. TSP's first attempt to be compatible was only partly successful. After the government loaned TSP one of SST's machines,

101. See, e.g., Brown Bag Software v. Symantec Corp., 960 F.2d 1465 (9th Cir.), cert. denied, 113 S.Ct. 198 (1992). See also Lalli, 936 F.2d 671 (conventional arrangement of information on horse racing form not protectable by copyright)

102. 982 F.2d 693 (2d Cir. 1992). The "filtration" analysis in Altai can be found id. at 709-10. See infra nn. 109-11 and accompanying text for further discussion of Altai.

103. See, e.g., Lake, Harwood, \& Olson, "Tampering With Fundamentals: A Critique of Proposed Changes in EC Software Protection," 6 Computer L. 1 (Dec. 1989).

104. Whelan, 797 F.2d at 1237-38. The Altai opinion indicates that Computer Associates made a similar argument. Altai, 982 F.2d at 711 .

105. See, e.g., Atari Games, 1993 U.S. Dist. Lexis 11653. See also Miller, supra n. 91 , at $1004,1026-34$.

106. 722 F. Supp. 1354 (E.D. Va. 1989). See also NEC v. Intel, 10 U.S.P.Q.2d (BNA) 1177 (N.D. Cal. 1989) (no infringement of microcode copyright because similarities were due to need to achieve compatibility). 
thereby giving TSP an opportunity to study SST's protocol variations, TSP was able to achieve complete compatibility with the SST machine. SST sued for copyright infringement. The court decided that SST's variations on the standard protocol lacked sufficient originality to support a copyright claim. ${ }^{107}$ The court also regarded SST's claims as precluded under policies of section 102(b). ${ }^{108}$

The major U.S. case concerning the copyright status of internal interface information is, however, Computer Associates Int'l, Inc. $v$ Altai, Inc. ${ }^{109}$ After Altai discovered that an ex-employee of CA, now working for it, had copied portions of CA's code into the part of its program that was to interface with the same IBM operating system programs as CA's program did, Altai undertook to rewrite the code by a "clean room" process. One person studied the infringing code to determine the interface specifications that would have to be reimplemented. A separate team of Altai engineers wrote new code to implement these interface elements. CA claimed that Altai's code nonetheless infringed because it was still similar in structure, sequence, and organization to CA's code, asserting that these similarities were the residue of expression copied from CA's program.

The court was, however, persuaded that most of the similarities between the two programs were due to external factors, principally the need to interoperate with IBM operating system programs. ${ }^{110}$ Other similarities were to be expected from programs of that kind. ${ }^{111}$ The court decided that remaining similarities were not substantial enough to constitute infringement. ${ }^{112}$

The court made clear that elements of programs needed to achieve interoperability with other programs were unprotectable by copyright law. ${ }^{113}$ The appellate court called for such elements to be

107. SST, 722 F. Supp. at 1362 .

108. SST claimed that the timing of its implementation of the protocol was expressive. The court rejected this as inconsistent with section 102(b): "[T]iming is nothing more than the process by which electronic signals are created, transmitted, [and] received. So viewed, electronic signaling is analogous to the size of an individual letter on a page of 'Hamlet.' "Id. at 1363, n. 25.

109. 775 F. Supp. 544 (E.D.N.Y. 1991), affd, 982 F.2d 693 (2d Cir. 1992). See also Sega, 977 F.2d 1510 (disassembling copyrighted software is not infringement if necessary to get access to functional requirements for achieving compatibility).

110. See Altai, 775 F. Supp. at 561, 982 F.2d at 714-15.

111. Id.

112. 775 F. Supp. at 562 .

113. 982 F.2d at 709-10. The court's discussion of the unprotectability of interface information can be found in the portion of the opinion in which the court discussed constraints on program design dictated by external factors. Although earlier and later parts of the opinion refer to the principles of section 102(b), Baker v. Selden, the merger doctrine, and lack of originality, the court does not make explicit on which of these doctrines it relies in denying copyright to interface requirements.

Interoperability considerations also underlie trends towards standardization in forms for electronic data interchange (EDI) of various sorts. To facilitate international EDI, concerned parties have formulated international standards for the structuring of electronic forms so that data can be rapidly and accurately exchanged. 
"filtered out" before an infringement comparison is made of the two works. 114

Although user interfaces are perceived in the technical community as raising similar compatibility considerations as internal interfaces, ${ }^{115}$ the US software copyright caselaw has tended to conceive of user interfaces quite differently from internal interfaces, principally because the former can be seen and the latter cannot. Similarities in user interfaces argued to be necessary to facilitate compatibility for users have sometimes been given credence, ${ }^{116}$ but other times they have not. ${ }^{117}$ In user interface cases, as in other computer program or fact compilation cases generally, it has become more common to consider functional constraints on the range of expression as bearing on the originality of the work as a whole or on the originality of the part of the work that has been copied. ${ }^{118}$

\section{B. Originality Issues as to Other Digital Works}

Computer programs are not the only class of works in digital form falling under the broad statutory definition of literary work which are likely to pose difficult originality questions in coming years. Computer databases, digitized versions of public domain works, computer-generated works, and the transmutability of works in digital form will also contribute problems to which copyright protection will sometimes be asserted as an answer. The key to availability of copyright protection will, in many cases, be whether the originality standard can be met.

One problem for copyright in databases has been identified by Professor Litman: "Under the Supreme Court's analysis [in Feist], a competitor would be infringing no copyright if it simply stole the data and left the base."119 Database firms also feel vulnerable because of several characteristics of computer databases that differentiate them from print compilations. First, many computer databases are created by automatic selection and arrangement of data which will make it

114. Altai, 982 F.2d at 706-12.

115. See, e.g., Spector, "Software, Interface, and Implementation," 30 Jurim. J. 79 (1989).

116. See, e.g., Microsoft, 799 F. Supp. at 1021. See also Plains Cotton Cooperative Ass'n v. Goodpasture Computer Service, Inc., 807 F.2d 1256, 1262 (5th Cir 1987).

117. See, e.g., Paperback, 740 F. Supp. at 68-70, 77-79. See also Digital Communications Associates, Inc. v. Softklone Distributing Corp., 659 F. Supp. 449 (N.D. Ga . 1987).

118. See, e.g., Bellsouth, (functional considerations constrained some choices of categories for yellow pages directory) and Microsoft, 799 F. Supp. at 1027 (functional considerations constrained user interface window design).

119. Litman, supra n. 12, at 609. But see Gorman, supra n. 5 (suggesting that creativity in selection may aid database providers in their efforts to protect their compilations through copyright law). 
difficult to claim copyright protection in the database. ${ }^{120}$ Second, regardless of whether copyright's originality requirement can be met, it is trivially easy and inexpensive to make multiple perfect copies of the contents of a computer database once one gets access to it. ${ }^{121}$ Third, once copied, data in a computer database can be easily reselected or rearranged through the use of automated tools. This may avoid any infringement of a copyright in the database from which the data came. ${ }^{122}$ Fourth, the data in the computer database will generally have a different underlying structure than it will have a presentation structure which may also complicate infringement determinations. ${ }^{123}$ Fifth, users may have the ability to cause the presentation structure of an electronic database to be dynamically readjusted by the kinds of queries users make of the base which further complicates infringement analysis. ${ }^{124}$ Sixth, computer data compilations are frequently updated, which means that they regularly change in content. ${ }^{125}$ The fact that the work is constantly changing means it can be difficult to say what the "work" really isunless the work is really the schema, and not the content arrayed in the framework established by the schema. ${ }^{126}$

120. See, e.g., Hart, "Copyright and Computer Generated Works," in SOFTIC Proceedings, supra n. 4, at 472 (satellite photography data). It seems unlikely after Feist that one could successfully argue that setting the parameters as to the frequency of an automatic collection of data would suffice as originality for copyright purposes.

121. See, e.g., Samuelson, "Digital Media \& The Changing Face of Intellectual Property Law," 16 Rutg. Comp. \& Techn. L. J. 323, 324-28 (1990) (noting that controls over access and use are the likely response to these characteristics of digital data).

122. See, e.g., New York Times Co. v. Roxbury Data Interface, Inc., 434 F. Supp. 217 (D. N.J. 1977) (rearrangement of data from New York Times index was noninfringing) and Gem Products, Inc. v. Robertshaw Controls Co., 229 U.S.P.Q.(BNA) 740 (C.D. Cal. 1986) (competitor's reproduction of the plaintiff's set of parts and model numbers into its computer database was noninfringing). But see Gorman, supra n. 5.

123. See, e.g., Samuelson, "Writing As a Technology," in, Peter Jaszi \& Martha Woodmansee (eds.), Cultural Agency/Cultural Authority: Politics and Poetics of Intellectual Property in the Post-Colonial Era (forthcoming 1994) (discussing the implications for copyright of differences between the underlying structure and presentation structure of works in digital form).

124. Id. (explaining that readers of digital texts become "users" able to transform any digital text into a database by different queries). This may help to explain why some copyright owners have argued that infringement should be found because of the potential for databases to be used to infringe. See supra n. 61 .

125. The Copyright Office has adopted some special regulations to aid in registration of computer databases. See, e.g., Peters, "The Copyright Office And the Formal Requirements of Registrationof Claims to Copyright," 17 U. Dayton L. Rev. 737 (1992). It may be that the law will eventually come to recognize a kind of "floating copyright" for updated informationbases (just as "floating liens" on inventories were developed to create meaningful security interests in them). For many databases as to which information is constantly updated, there will be substantial market protection for the updated product because any copy that might be made of the database by a competitor would be rapidly outdated.

126. See, e.g., Kregos, 937 F.2d 700 (format, rather than content that changed daily, was claimed as the copyrightable work). There have been a few cases in recent years raising questions about what is a "work" for copyright purposes. See, e.g., Grundberg v. Upjohn Co., 1991 Cop. L. Dec. (CCH) \26,792, (D. Utah 1991) (rejecting 
Although some U.S. commentators are optimistic that copyright can easily deal with commercially significant misappropriations of data from databases, ${ }^{127}$ it remains to be seen whether these predictions will be justified. There are at least two factors that may eventually contribute to a U.S. decision to adopt a sui generis regime for data compilations similar to that proposed by the EC. First, U.S. courts may become more attentive to policies underlying section 102(b) and may more frequently deny copyright to methodical data compilations. ${ }^{128}$ Secondly, if the EC adopts a database directive with a reciprocity provision that would render U.S. database firms vulnerable to copying from their databases by European firms unless the U.S. has a similar database protection law, U.S. firms may press for a similar U.S. law. ${ }^{129}$ Since U.S. database firms have a significant presence in the EC database market, they do not welcome the EC initiative. ${ }^{130}$ Perhaps, U.S. firms will be able to use contractual or technical means to protect their electronic data compilations in the EC.

Digitization of texts, and the concomitant processing of them that computer programs make possible, are likely to create other demands that copyright protection should be extended to other works of questionable originality. In one recent case, a claim of copyright was made in a digitized "version" of classic literature works (i.e., public domain works) which ended with entry of a judgment forbidding further copying of the plaintiff's work in digital form. ${ }^{131}$ West Publishing has also recently instituted suit against the vendor of a CD-ROM containing electronic versions of cases that West claims infringes its

claim that 90,000 pages of company documents that had been produced during a prior litigation comprised a single unpublished copyrighted work, partly because of an intent to use copyright to thwart access by the public to information contained in the documents). See also Sem-Torq, Inc. v. K-Mart Corp., 936 F.2d 851 (6th Cir. 1991) (set of five doublesided signs was not a copyrightable compilation because, although they were displayed as a set, they were sold individually). In the physical world, it may be easier than it will be in the digital realm to tell where one work ends and another begins. If the 90,000 documents in Grundberg were stored on a CDROM, they would look more like a single work. In the digital realm, whole libraries will seem to be a single work. See Samuelson, Digital Media, supra n. 121 at 335.

127. See, e.g., Gorman, supra n. 5 and Miller, supra n. 91.

128. See supra nn. 48-50 and accompanying text.

129. See Proposed Directive, supra n. 13, at Art. 11.

130. See, e.g., Band \& McDonald, "The Proposed EC Database Directive: The "Reversal' of Feist v Rural Telephone," 9 Computer L. 19 (June 1992) (information industry lawyers critical of EC Proposed Directive).

131. World Library, Inc. v. Pacific Hitech, Inc., No. C-93-20530-JW (N.D. Cal. 1993). There was considerable discussion about this case on the cni-copyright listserv (an Internet electronic exchange service focused on copyright issues), during which attorney Patrice Lyons mentioned that an ABA committee with which she had been working was investigating use of copyright as a way to protect digital versions of public domain documents. See also Karjala, "Copyright and Misappropriation," 17 . Dayton L. Rev. 885, 906-07 (1992). I have serious doubts that the same Supreme Court that decided Feist would find digitizing public domain texts to satisfy the originality requirement for a new copyright in the work. 
copyrights in the Southern Reporter series of state court judicial decisions. ${ }^{132}$ If the current legislative proposal to drop the requirement for U.S. authors of having to register with the Copyright Office before an infringement suit can be brought becomes law, ${ }^{133}$ claims of copyright in electronic "versions" of public domain works may rise substantially. ${ }^{134}$

Although much discussed in the law review literature, ${ }^{135}$ no cases have yet dealt with claims of copyright in computer-generated works. ${ }^{136}$ Before Feist, it was relatively easy to argue such works might be claimed as the original work of the user who generated them. ${ }^{137}$ In the aftermath of Feist, it may be that a sui generis solution will be needed for the protection of such works as well, for the Court seemed intent on finding a spark of human creativity or judgment at the time the work was created as a precondition for copyright protection. ${ }^{138}$

Some challenging copyright issues will likely also derive from the fact that virtually all categories of copyrighted works can now be represented in digital form. ${ }^{139}$ Digitized as the 1's and 0's of the binary domain, they become "works expressed in...numerical symbols or indicia." In other words, all works in digital form are "literary works"

132. West Pub. Co. v. On Point Solutions, Civ. No. 1-93-CV-2071-MHS (N.D. Ga.). West also claims unfair competition. The author has also spoken to a law professor who after downloading cases from one of the electronic databases of legal decisions, had begun to construct an electronic casebook from the downloaded decisions. She intended to make this casebook available to her students. Although she deleted everything except the actual texts of the cases, she has been informed by the database provider that use of that firm's electronic versions of cases in her casebook would constitute infringement. The firm told her it would take legal action against her if she distributed her casebook.

133. Copyright Reform Act of 1993, S. 373 and H.R. 897, printed in 45 Patent, Copyright, \& Trademark J. (BNA) 329 (Feb. 18, 1993).

134. The Copyright Office currently denies registration to thousands of "works of low authorship," as Professor Ginsburg calls them. See supra n. 22 and accompanying text.

135. See, e.g., Miller, supra n. 91 and Samuelson, "Allocating Ownership Rights in Computer-Generated Works," 47 U. Pitt. L. Rev. 1185 (1986).

136. Many copyrighted works are, of course, created with the aid of a computer. Mere use of a computer does not diminish the authorship of a work's creator. But some computer systems generate works as to which the only act of creation by a human may be the clicking of a mouse or hitting a return key. Examples of such works are given in Office of Technology Assessment, Intellectual Property Rights In an Age of Electronics and Information 70-72 (1986).

137. See Samuelson, supra n. 135 (pre-Feist article arguing that the user who caused the work to be generated could meet copyright's low originality standard).

138. See Feist, 111 S.Ct. at 1288 . The United Kingdom has a copyright-based sui generis law for protection of computer-generated works. The European Community will likely adopt a sui generis regime for computer-generated works which do not meet the human authorship requirement. See, e.g., Hart, supra n. 120, at 467-77.

139. Even sculptural forms can be rendered in three-dimensional computer graphics software, such that one can experience moving around them and studying them from different angles. See, e.g., Chapin, "Design Space," in, Visual Proceedings of ACM Computer Graphics Conference 194-95 (1993). 
under the U.S. statutory definition, even though when processed by the appropriate software and hardware, they may be sound recordings, musical works, pictures or photographs. ${ }^{140}$

The originality standard for literary works will thus become the originality standard for virtually all classes of works in the digital realm. ${ }^{141}$ This might not seem troublesome in that, at least theoretically, the originality standard of copyright law is supposed to be the same regardless of the class of work involved.142 Further contributing to the conflation of copyright's classification scheme for different kinds of works, however, is the fact that in digital form, works can be processed so that they are, in fact, more than one kind of work at the same time with the aid of electronic information tools. ${ }^{143}$ That is, a digitized picture may be processed to be a set of sounds, or digitized sounds to be a picture. ${ }^{144}$ It will be interesting to see if the originality of the work as a picture will suffice to support its protection by copyright as a set of sounds.

In short, there are many questions for copyright lawyers in the U.S. to address pertaining to the originality standard for digital "literary works." The challenge will be to answer them in a way that is both consistent with traditional principles of copyright law and with what is economically sensible practice.

140. Recall that "literary work" is defined so broadly that audiovisual works would fall within its bounds if not for an explicit exclusion. See supra $n .2$. While some might suggest that "literary work" will have to be amended to exclude these other categories of works as well, it is more likely that the historical distinctions among various kinds of works and special rules pertaining to them will cease to be useful over time.

141. Samuelson, supra n. 121, at 332-34 (discussing the copyright consequences of the equivalence of works in digital form).

142. The equivalence of works in digital form may, however, lead to some significant changes in copyright law. In the not too distant future, the multiplicity of special rules based on distinctions among different kinds of works is likely either to cease or substantially diminish. If one examines the provisions found in 17 U.S.C. $\$ 108-120$, it is apparent that many of these provisions apply only to some classes of works and not to others. In $\$ 108$, for example, certain privileges apply to literary works but not to musical or pictorial works. In digital form, pictures and sound recordings fall within the definition of literary work, yet it is unclear that the law would treat digitized pictures or sound recordings as qualifying for the $\$ 108$ privilege.

143. See, e.g., Samuelson, "Fair Use For Computer Programs and Other Copyrightable Works in Digital Form," 1 J. Intell. Prop. L. (forthcoming 1993). I have borrowed the term "electronic information tool" from Professor Reichman. See Reichman, supra n. 15.

144. See Samuelson, supra n. 143 (giving examples of pictorial works processed to produce sound and sounds as pictures). 
HeinOnline -- 42 Am. J. Comp. L. Supp. 4181994 